\title{
Assessment of Chlorophyll-a Remote Sensing Algorithms in a Productive Tropical Estuarine-Lagoon System
}

\author{
Regina Camara Lins ${ }^{1}$, Jean-Michel Martinez ${ }^{2}$, David da Motta Marques ${ }^{3}$, José Almir Cirilo ${ }^{1}$ \\ and Carlos Ruberto Fragoso Jr. ${ }^{4, *}$ \\ 1 Department of Civil Engineering, Federal University of Pernambuco, 50670-901 Recife, Brazil; \\ reginacamaralins@hotmail.com (R.C.L.); almir.cirilo@gmail.com (J.A.C.) \\ 2 Géosciences Environnement Toulouse (GET), Unité Mixte de Recherche 5563, IRD/CNRS/Université \\ Toulouse III, 31400 Toulouse, France; martinez@ird.fr \\ 3 Hydraulic Research Institute, Federal University of Rio Grande do Sul, CP 15029 Porto Alegre, Brazil; \\ dmm@iph.ufrgs.br \\ 4 Center for Technology, Federal University of Alagoas, 57072-970 Maceió, Brazil \\ * Correspondence: ruberto@ctec.ufal.br; Tel.: +55-82-996-328-814
}

Academic Editors: Yunlin Zhang, Claudia Giardino, Linhai Li, Deepak R. Mishra and Prasad S. Thenkabail Received: 27 February 2017; Accepted: 19 May 2017; Published: 24 May 2017

\begin{abstract}
Remote estimation of chlorophyll-a in turbid and productive estuaries is difficult due to the optical complexity of Case 2 waters. Although recent advances have been obtained with the use of empirical approaches for estimating chlorophyll-a in these environments, the understanding of the relationship between spectral reflectance and chlorophyll-a is based mainly on temperate and subtropical estuarine systems. The potential to apply standard NIR-Red models to productive tropical estuaries remains underexplored. Therefore, the purpose of this study is to evaluate the performance of several approaches based on multispectral data to estimate chlorophyll-a in a productive tropical estuarine-lagoon system, using in situ measurements of remote sensing reflectance, $R_{r s}$. The possibility of applying algorithms using simulated satellite bands of modern and recent launched sensors was also evaluated. More accurate retrievals of chlorophyll-a $\left(r^{2}>0.80\right)$ based on field datasets were found using NIR-Red three-band models. In addition, enhanced chlorophyll-a retrievals were found using the two-band algorithm based on bands of recently launched satellites such as Sentinel-2/MSI and Sentinel-3/OLCI, indicating a promising application of these sensors to remotely estimate chlorophyll-a for coming decades in turbid inland waters. Our findings suggest that empirical models based on optical properties involving water constituents have strong potential to estimate chlorophyll-a using multispectral data from satellite, airborne or handheld sensors in productive tropical estuaries.
\end{abstract}

Keywords: shallow productive estuary; chlorophyll-a; remote sensing; Sentinel

\section{Introduction}

Estuarine systems, which are transitional complex zones between rivers and oceans, exhibit spatial variability, seasonal cycles and distributions of organisms strongly influenced by various environmental factors, most notably: (a) a spatio-temporal salinity gradient; (b) high variability of temperature and light intensity; (c) inflow and nutrient discharge; and (d) hydrodynamic patterns [1]. These specific features make estuaries among the most productive habitats in the world, as they provide natural resources to maintain the use of local fisheries and aquaculture, allowing significant socio-economic development [2]. 
Although numerous physical and biological characteristics of these systems are well-known, their susceptibility to anthropic aggression (e.g., effluent discharge, fishing and aquiculture), which affects the trophic structure, has also been recognized [3]. For instance, the continuous increase in both nutrient loading and organic matter has led to estuaries with higher eutrophication levels. This degradation process usually results in an increase in water turbidity due to blooms of cyanobacteria or green algae, which subsequently affect the entire trophic structure. Thus, methodological approaches to quantify eutrophication are essential to improve the understanding of the ecosystem dynamics of estuaries and to develop tools for accurate decision making.

Long-term monitoring of chlorophyll-a (a phytoplankton biomass indicator) is frequently carried out to assess the eutrophic state of an estuary [4-6]. However, this monitoring requires representative (in time and space) field sampling and laboratory measurements to adequately cover the distribution of phytoplankton. Unfortunately, it is not always possible to have technical and financial resources available to carry out such monitoring, mainly in estuaries that exhibit high spatio-temporal heterogeneity [7].

Data from satellite sensors may provide better information on chlorophyll-a variability in comparison to conventional field monitoring because most modern sensors (e.g., Moderate Resolution Imaging Spectroradiometer (MODIS), Medium Resolution Imaging Spectrometer (MERIS) and Sea-viewing Wide Field-of-view Sensor (SeaWiFS)) have improved capabilities with respect to spectral, radiometric, temporal and spatial resolutions [8-10]. Recent advances have resulted in significant progress in the remote assessment of chlorophyll-a in turbid and productive waters [11]. However, some problems, such as atmospheric correction and complexity of optical properties involving water constituents, make it difficult to use a simple and universal empirical algorithm to estimate chlorophyll-a from satellite data, being an additional challenge to inland water remote sensing [12,13]. Therefore, for a geographic and/or seasonal region, it is essential to conduct a thorough investigation of the local relationships between in situ-measured chlorophyll-a and spectral bands of airborne or handheld sensors before using satellite datasets [14].

In general, these empirical algorithms are often based on a relationship between chlorophyll-a and reflectance, $R_{r s}(\lambda)$, which is derived from the bio-optical theory of inherent optical properties (IOPs), such as total absorption $(a)$ and backscattering $\left(b_{b}\right)$ coefficients $[15,16]$. The underlying principle is that changes in the concentrations and distribution of organic and inorganic particulates and dissolved substances in the water affect the observed reflectance, $R_{r s}(\lambda)$, in different wavelengths, $\lambda$, according to Gons [17] and Preisendorfer [18]:

$$
\begin{gathered}
R_{r s}(\lambda)=\frac{f(\lambda)}{Q(\lambda)} \frac{b_{b}(\lambda)}{a(\lambda)+b_{b}(\lambda)} \\
a=a_{C h l-a}+a_{N A P}+a_{C D O M}+a_{\text {water }} \\
b_{b}=b_{b, \text { water }}+b_{b, \text { particles }}
\end{gathered}
$$

where $f(\lambda)$ describes the sensitivity of the reflectance to variations in the solar zenith angle [19], and $Q(\lambda)$ expresses the bidirectional properties of reflectance [20]; $a_{C h l a}, a_{N A P}, a_{C D O M}$ and $a_{\text {water }}$ are the chlorophyll-a, the non-algal particles (NAP), the colored dissolved organic matter (CDOM) and the pure water absorption coefficients, respectively; and $b_{b, w a t e r}$ and $b_{b \text {,particles }}$ are backscattering due to water and organic/inorganic particles in suspension, respectively. As values for both $a_{w a t e r}$ and $b_{b, \text { water }}$ can be assigned as constants [21-23], it is still necessary to identify the contribution of some important optically active compounds (i.e., $a_{N A P}, a_{C D O M}$ and $b_{b, p a r t i c l e s}$ ) in order to estimate chlorophyll-a concentrations from multispectral data.

With respect to oligotrophic and clear waters, Case 1 [24], reflectance in the blue region is dominated by the spectral response of chlorophyll-a, which has an absorption maximum around $440 \mathrm{~nm}$. In these environments, models based on the blue/green ratio have shown the best performance [25-27] since CDOM and NAP show a strong correlation with chlorophyll-a because 
these constituents are derived from processes related to phytoplankton (i.e., mortality and exudation). However, in turbid and productive waters, i.e., Case 2 waters (IOCCG 2000), blue/green ratio models do not adequately represent the chlorophyll-a variability since CDOM and NAP may originate from additional sources, such as runoff of sediments, nutrients and organic matter and the resuspension of sediments from shallow bottoms [28,29].

Thus, major efforts have been made in the last decade to test and evaluate different algorithms to estimate chlorophyll-a in inland and coastal waters using multispectral data from datasets with different sources, such as handheld, airborne or spaceborne sensors [30-43]. In turbid and productive estuaries, the best empirical approaches for estimating chlorophyll-a have been obtained with the use of NIR-Red models $[44,45]$. However, the understanding of these relationships has mainly focused on temperate and subtropical estuarine systems using modern satellite sensors, such as MODIS, MERIS and SeaWiFS [14,30,44-48]. Therefore, there is a notable lack of knowledge on bio-optical variability in tropical estuarine systems, which could be a novel branch for scientific investigations to develop new spectral reflectance-based models using in situ measured (i.e., spectral reflectance and chlorophyll-a) or satellite-derived data, especially for recently launched satellite, such as Sentinel-2 and Sentinel-3, which opened a new potential to estimate chl-a in optically complex waters where fine spectral, spatial and temporal resolutions are required [49]. Moreover, this work is one of the first assessing the variability of the water color of a tropical lagoon contributing to expand the knowledge of inland water optical properties.

The purpose of this study is to evaluate the performance of several approaches based on spectral bands to estimate chlorophyll-a in a productive tropical estuarine-lagoon system, using in situ observations. The possibility of applying the algorithm to remote sensing satellite images of modern and recent spaceborne sensors is also discussed in this study. This knowledge is a first step towards obtaining comprehensive and reliable reflectance-based models for tropical turbid and productive waters, which may be further tested with satellite data in order to remotely estimate chlorophyll-a.

\section{Materials and Methods}

\subsection{Study Area}

The Mundaú-Manguaba Estuarine-Lagoon System (MMELS) is a shallow (max. depth of $3.5 \mathrm{~m}$ ) tropical lagoon system located in the state of Alagoas, northeastern Brazil, between $9^{\circ} 35^{\prime} 00^{\prime \prime} \mathrm{S}$ and $9^{\circ} 46^{\prime} 00^{\prime \prime} \mathrm{S}$ latitude and $35^{\circ} 34^{\prime} 00^{\prime \prime} \mathrm{W}$ and $35^{\circ} 58^{\prime} 00^{\prime \prime} \mathrm{W}$ longitude (Figure 1 ). The system is composed of three compartments: (a) the Mundaú Lagoon $\left(27 \mathrm{~km}^{2}\right)$ in the eastern MMELS, which receives freshwater mainly from the Mundaú river basin (annual average discharge of $35 \mathrm{~m}^{3} / \mathrm{s}$ ); (b) the Manguaba Lagoon $\left(42 \mathrm{~km}^{2}\right)$ in the western MMELS, which receives an average annual fresh water discharge of $28 \mathrm{~m}^{3} / \mathrm{s}$ from the Paraíba do Meio and Sumaúma river basins; and (c) the mangrove-lined narrow channel system $\left(12 \mathrm{~km}^{2}\right)$, which connects both lagoons via a single $250 \mathrm{~m}$ wide tidal inlet to the Atlantic Ocean. MMELS exhibits a tropical semi-humid climate with well-defined dry (from October to December) and wet (from May to July) seasons. The average annual mean temperature is $25^{\circ} \mathrm{C}$, and the winds blow predominantly from a southeasterly direction, governed mainly by trade winds in summer [50]. Manguaba lagoon is generally less saline than Mundaú lagoon. However, both lagoons are characterized by eutrophic conditions and are dominated by phytoplankton. Additional physical characteristics of the Mundaú and Manguaba lagoons can be observed in Table 1. 
Table 1. Main physical features of the Mundaú and Manguaba lagoons.

\begin{tabular}{ccc}
\hline Features & Mundaú & Manguaba \\
\hline Volume $\left(106 \mathrm{~m}^{3}\right)$ & 43 & 97.7 \\
Average depth $(\mathrm{m})$ & 1.5 & 2.2 \\
Tidal range $(\mathrm{m})$ & 0.2 & 0.03 \\
Tidal prism $\left(106 \mathrm{~m}^{3}\right)$ & 17.3 & 6.1 \\
Average freshwater discharge $\left(\mathrm{m}^{3} / \mathrm{s}\right)$ & 35 & 28 \\
Retention time (days) & 16 & 36 \\
\hline
\end{tabular}

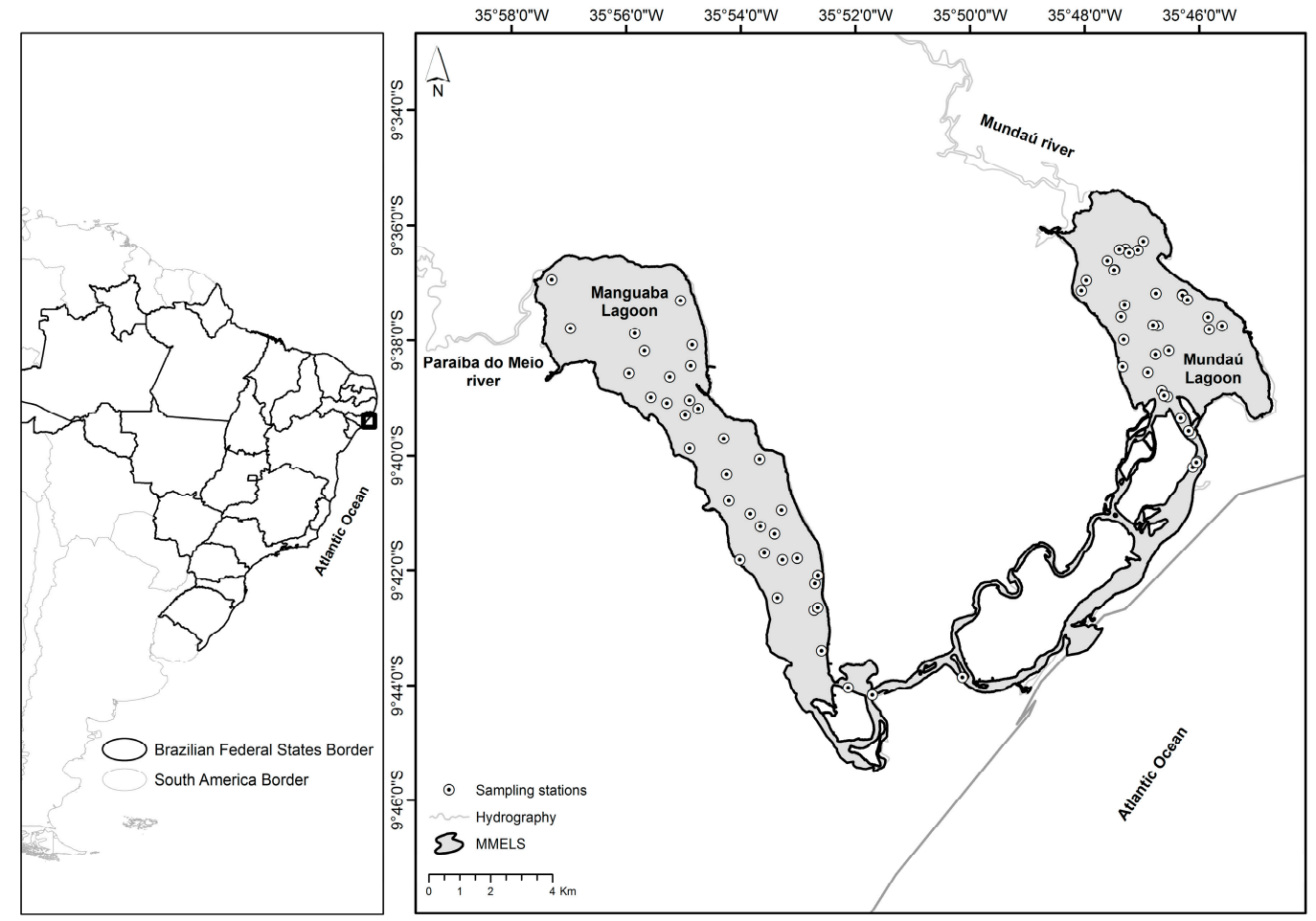

Figure 1. Mundaú-Manguaba Estuarine-Lagoon System (MMELS) study site and spatial distribution of sampling stations, which were used to collect water samples and reflectance measurements.

\subsection{Field Measurements}

Shipboard data were collected during six major field campaigns conducted between May and September 2015. During each field campaign, a set of 12 sampling stations, well-distributed across MMELS, was established (Figure 1). At each sampling station, above-water optical measurements and water sample collection for laboratory analysis were carried out simultaneously. Surface water samples (each sample $=2.0 \mathrm{~L}$ volume) were collected at a depth of $0.2 \mathrm{~m}$ below the water surface. The samples were stored in a cooler with ice under dark conditions and were transported to the laboratory to determine the chlorophyll-a (Chl-a) and total suspended solids (TSS) concentrations. Above-water hyperspectral reflectance measurements were performed using TriOs RAMSES radiometers, with a spectral resolution of approximately $3.3 \mathrm{~nm}$, following the ocean optics protocols recommended by NASA (see [51]). All of the radiometers were mounted in an aluminum pole vertically positioned on the top of the boat. An irradiance sensor (operating in the range 350-721 nm) was used to measure downwelling irradiance above the water surface, $E_{d}(\lambda)$, and two radiance sensors (operating in the range 350-950 $\mathrm{nm}$ with a $7^{\circ}$ field of view) were used to measure upwelling radiance above the surface water, $L_{u}(\lambda)$, as well as the sky radiance that was used to correct for the skylight reflection effect at the air-water interface, $L_{s}(\lambda)$. 
The remote sensing reflectance, $R_{r s}(\lambda)$, was calculated as follows:

$$
R_{r s}(\lambda)=\frac{L_{u}(\lambda)-\rho \cdot L_{s}(\lambda)}{E_{d}(\lambda)}
$$

The above-water upwelling radiance, $L_{u}$, is the sum of the upwelling radiance, $L_{w}\left(0_{+}\right)$, and the sky radiance directly reflected by the air-water interface, $L_{r}$. Because only $L_{u}$ is directly measureable, and $L_{w}\left(0_{+}\right)$and $L_{r}$ are not measured, $L_{r}$ is assessed as $L_{r}=\rho \cdot L_{s}$, where $\rho$ is a proportionality factor. The factor $\rho$ is not an inherent optical property of the surface and is dependent on the sky conditions, wind speed, solar zenith angle, and viewing geometry. Mobley [52] used a radiative transfer code to estimate the variability of $\rho$ as a function of the different forcing factors. These results showed that when $L_{u}$ was acquired with a viewing direction of $40^{\circ}$ from the nadir and $135^{\circ}$ from the sun, the variability of $\rho$ was considerably reduced under clear-sky conditions, and a value of 0.028 was considered acceptable at wind speeds less than $5 \mathrm{~m} \cdot \mathrm{s}^{-1}$. Finally, $L_{w}\left(0_{+}\right)$was calculated by the subtraction of $L_{u}$ and $\rho \cdot L_{s}$. To limit the effects of external factors, all radiometric measurements were acquired within the viewing geometry defined by Mobley [52], under low-wind $\left(0-4 \mathrm{~m} \cdot \mathrm{s}^{-1}\right)$ and clear-sky conditions, and for sun zenith angles ranging from 0 to $30^{\circ}$.

\subsection{Water Sample Analysis}

All samples were filtered on land, no later than $12 \mathrm{~h}$ after sampling, using Whatman GF/F glass fiber filters (pore size of $0.45 \mu \mathrm{m}$ ). The filters were wrapped in aluminum foil and kept frozen until analysis. Chlorophyll-a from algae concentrated on filters was extracted into $90 \%$ ethanol for $18 \mathrm{~h}$ in an amber flask and measured using a spectrophotometric trichromatic method [53]. Water samples also were analyzed for total suspended solids (TSS), which were filtered using Whatman GF/F filters; the residue retained was dried to a constant weight at 103 to $105^{\circ} \mathrm{C}$ and measured gravimetrically [53].

\subsection{Reflectance Spectra Classification}

All 72 reflectance spectra were classified into four homogeneous groups, which were sufficient to identify possible spatial or temporal dependencies in the remote sensing reflectance data. The optical classes were divided using a k-means clustering analysis, an unsupervised classification technique that categorizes the data set based on the natural distribution of the data in multivariate space. Each $R_{r s}(\lambda)$ spectrum was previously normalized by its integral, calculated over the entire spectrum [54], in order to enhance the spectral shape of the $R_{r s}(\lambda)$ spectra in the classification. This classification may support the use of multiple retrieval algorithms for each lagoon, homogeneous regions or a global retrieval algorithm for a whole system [55].

\subsection{Models to Estimate Chlorophyll-a from $R_{r s}(\lambda)$}

Among several models used to estimate chlorophyll-a in inland waters from spectral reflectance data (see a review conducted by Matthews [56]), we evaluated the performance of four algorithms using the available dataset. The following models were chosen due to their wide and successful use in previous studies and because these algorithms are based on physical fundamentals.

\subsubsection{The Blue-Green Ratio Model}

The first tested model to estimate chlorophyll-a uses a simple ratio between reflectance in the blue region at $440 \mathrm{~nm}, R\left(\lambda_{\text {Blue }}\right)$, in which Chl-a and carotenoids strongly absorb light, and reflectance in the green region at $550 \mathrm{~nm}, R\left(\lambda_{\text {Green }}\right)$, where reflectance is minimally absorbed by pigments. This model was initially proposed by Morel and Prieur [24], and it is still widely used for ocean color [25,27].

$$
\text { Chla } \propto R\left(\lambda_{\text {Blue }}\right) / R\left(\lambda_{\text {Green }}\right)
$$




\subsubsection{The Two-Band NIR-Red Ratio Model}

The second tested model follows the same principle of the blue-green ratio model, but it considers a ratio between reflectance in the near-infrared, $R\left(\lambda_{N I R}\right)$, and reflectance in the red region, $R\left(\lambda_{R e d}\right)$, according to:

$$
\text { Chla } \propto R\left(\lambda_{N I R}\right) / R\left(\lambda_{R e d}\right)
$$

where $\lambda_{\text {Red }}$ is a wavelength usually located around the point of maximum chlorophyll-a absorption, which is restricted to the range $660 \mathrm{~nm}<\lambda_{\text {Red }}<690 \mathrm{~nm}$ [33]. One may assume that the absorption by non-algal particles, yellow substances and backscattering can be considered non-significant in comparison to the chlorophyll-a concentration in this wavelength, or $a_{c h l-a}\left(\lambda_{1}\right)>>a_{N A P}\left(\lambda_{1}\right)+a_{C D O M}\left(\lambda_{1}\right)$ and $a_{c h l-a}\left(\lambda_{1}\right) \gg b_{b}\left(\lambda_{1}\right)$. In general, the near-infrared wavelength, $\lambda_{N I R}$, may be found at two different positions in the NIR: (a) between $700 \mathrm{~nm}$ and $720 \mathrm{~nm}$, known as $\lambda_{2}$ [39,44,57], where absorption of the water constituents is minimal; or (b) beyond $710 \mathrm{~nm}$, known as $\lambda_{3}[31,45,58]$, where absorption is mostly dominated by water (i.e., $\left.a_{c h l-a}+a_{N A P}+a_{C D O M} \sim 0\right)$. In general, $b_{b}(\lambda)$ may be assumed to be approximately equal at both wavelengths.

\subsubsection{The Three-Band NIR-Red Model}

This model was initially developed to estimate pigments in terrestrial vegetation, but it has recently been used to determine chlorophyll-a in turbid and productive waters $[14,31,33,35]$. The algorithm has the form

$$
\text { Chla } \propto\left[R\left(\lambda_{1}\right)^{-1}-R\left(\lambda_{2}\right)^{-1}\right] \times R\left(\lambda_{3}\right)
$$

where $R\left(\lambda_{i}\right)$ is the measured reflectance in the spectral band $\lambda_{i}$. Similar to the two-band NIR-Red ratio model, $\lambda_{1}$ is the wavelength at which maximum chlorophyll-a absorption occurs.

This approach is based on the following three assumptions: (a) effect of CDOM and detrital absorption on $R\left(\lambda_{1}\right)$ is significant in the two-band ratio model, which can be minimized by subtraction of $R\left(\lambda_{2}\right)$; (b) the absorption of these constituents must be approximately the same at both wavelengths $\lambda_{1}$ and $\lambda_{2}$ (i.e., $a_{N A P}\left(\lambda_{2}\right)+a_{C D O M}\left(\lambda_{2}\right) \approx a_{N A P}\left(\lambda_{1}\right)+a_{C D O M}\left(\lambda_{1}\right)$ ); and (c) the chlorophyll-a absorption in $\lambda_{2}$ must be much smaller than that in $\lambda_{1}\left(a_{\text {chl-a }}\left(\lambda_{2}\right)<<a_{\text {chl-a }}\left(\lambda_{1}\right)\right)$. Dall'Olmo, Gitelson and Rundquist [31] suggested $\lambda_{2}$ values between $690 \mathrm{~nm}$ and $730 \mathrm{~nm}$. The third band, $\lambda_{3}$, is used to compensate the variability in backscattering between samples, and it is usually located where absorption is dominated by water with the same recommended range of the previous model. At this position, $R\left(\lambda_{3}\right)$ is influenced by backscattering only, and the backscattering, $b_{b}(\lambda)$, is approximately equal at the three wavelengths.

\subsubsection{The Four-Band NIR-Red Model}

The four-band model was developed by Le [36] to improve the performance of the three-band model for highly turbid waters. A fourth band, $\lambda_{4}$, located at NIR wavelengths, was included to minimize the impacts of absorption and backscattering of suspended solids in $\lambda_{3}$ [36,38]. Therefore, CDOM and detrital absorptions at $\lambda_{4}$ are similar to those at $\lambda_{3}$ (i.e., $a_{N A P}\left(\lambda_{4}\right)+a_{C D O M}\left(\lambda_{4}\right) \approx a_{N A P}\left(\lambda_{3}\right)+a_{C D O M}\left(\lambda_{3}\right)$ ), and $b_{b}(\lambda)$ is approximately equal at all four wavelengths.

$$
\text { Chla } \propto\left[R\left(\lambda_{1}\right)^{-1}-R\left(\lambda_{2}\right)^{-1}\right] /\left[R\left(\lambda_{4}\right)^{-1}-R\left(\lambda_{3}\right)^{-1}\right]
$$

\subsection{Algorithm, Model Evaluation and Validation}

An algorithm was developed in MATLAB ${ }^{\circledR}$ to identify the optimal wavelength positions in the NIR-Red models based on reflectance measurements. This algorithm consists of testing all possible sets of linear best-fit functions between observed and estimated chlorophyll-a within the 
spectral ranges recommended in previous studies for each optimal wavelength. Thus, a linear best-fit function was chosen for each model considering the following, in sequential order: the maximum and minimum values of the coefficient of determination $\left(r^{2}\right)$ and the root-mean square error (RMSE) of each chlorophyll-a model. The models were evaluated considering different subsets, such as MMELS, Mundaú lagoon, Manguaba lagoon and optical classes defined in the reflectance spectra classification.

In order to evaluate the accuracy and stability of the best models based on reflectance measurements, the MMELS dataset was divided into calibration and independent validation subsets. The models were calibrated using data collected from $2 / 3$ of the total number of stations, corresponding to the first two field campaigns for each lagoon, and were validated using data collected from $1 / 3$ of the stations, which corresponded to the last field campaign for each lagoon. Validation analysis was not extended to smaller subsets (e.g., Mundaú lagoon, Manguaba lagoon or optical classes) in order to reduce risks associated with obtaining non-representative samples for both calibration and validation sets.

\subsection{Retrieval of Chlorophyll-a Using Models Based on Simulated Satellite Bands}

Satellite bands were simulated using reflectance measurements in order to check the potential for satellite application in MMELS. For this analysis, we only selected satellite sensors capable of accurately describing the spatial-temporal variability of the optical properties in the MMELS, considering the size and retention time of the lagoons (see Table 1). Such physical features limited the use of most sensors with free satellite imagery, which have spatial and temporal resolutions larger than $500 \mathrm{~m}$ and one week, respectively. These criteria resulted in the selection of four satellite sensors (Table 2): (a) the still operational NASA sensors, MODIS-Terra (launched in 1999) and MODIS-Aqua (launched in 2002); (b) the non-operational MERIS sensor associated with the Envisat satellite, which was launched by ESA's Copernicus programme (2002-2013); (c) the MSI (MultiSpectral Imager) sensor related to Sentinel-2A (launched in June 2015) and Sentinel-2B (launched in March 2017); and (d) ESA's OLCI (Ocean and Land Colour Instrument) sensor on-board Sentinel-3A (launched in February 2016), which has visible and short-wave infrared radiances for ocean, inland and coastal waters in order to reach levels of accuracy and precision equivalent to those of the MERIS sensors.

Table 2. Characteristics of sensors and their associated satellites used to retrieve chlorophyll-a information in MMELS.

\begin{tabular}{|c|c|c|c|c|c|c|}
\hline \multirow[b]{2}{*}{ Sensor } & \multirow[b]{2}{*}{ Satellite } & \multicolumn{4}{|c|}{ Resolution } & \multirow[b]{2}{*}{ Central Wavelength $(400-900 \mathrm{~nm})$} \\
\hline & & $\begin{array}{l}\text { Spectral } \\
\text { (Bands) }\end{array}$ & $\begin{array}{l}\text { Temporal } \\
\text { (Days) }\end{array}$ & $\begin{array}{l}\text { Radiometric } \\
\text { (Bit) }\end{array}$ & $\begin{array}{l}\text { Spatial } \\
(\mathrm{m})\end{array}$ & \\
\hline MODIS & Terra/Acqua & 36 & 1 & 12 & $\begin{array}{l}250 \\
500\end{array}$ & $\begin{array}{l}645,858^{*} \\
469,555\end{array}$ \\
\hline MERIS & Envisat & 15 & 3 & 16 & 300 & $\begin{array}{c}412,443,490,510,560,620,665,681,709,754^{*} \\
761 *, 779^{*}, 865^{*}, 885^{*}\end{array}$ \\
\hline MSI & Sentinel-2 & 13 & $<5$ & 12 & $\begin{array}{l}10 \\
20 \\
60\end{array}$ & $\begin{array}{c}490,560,665,842 * \\
705,740,783,865 * \\
443\end{array}$ \\
\hline OLCI & Sentinel-3 & 21 & $<2$ & 16 & 300 & $\begin{array}{l}400,412,442,490,510,560,620,665,674,681, \\
709,754^{*}, 761 *, 764^{*}, 767^{*}, 779 *, 865 *, 885^{*}\end{array}$ \\
\hline
\end{tabular}

* Bands beyond the spectral range of operation of the $R_{r s}$ measured in-situ.

MODIS and MERIS sensors have been widely used to estimate chlorophyll-a in inland and coastal waters $[35,40,46]$, which can allow time-series reconstitution of the last 20 years. The recently available sensors MSI and OLCI (successor of MERIS) have a good spatial and temporal resolution and new spectral bands, which were positioned at strategic locations to improve chlorophyll-a estimates.

The best NIR-Red models using reflectance measurements with $r^{2}>0.8$ were chosen to test the performance of the band models using satellite-based wavelengths. The optimal positions found in the 
models based on $R_{r s}$ measured in-situ were tuned to the nearest simulated satellite bands, which were obtained using $R_{r s}$ in-situ data weighted according to the corresponding spectral response function (SRF) of each ocean color sensor.

\section{Results}

\subsection{Constituent Concentrations}

Notably, the chlorophyll-a and TSS concentrations in the water samples exhibited high variability (Table 3). The levels of chlorophyll-a differed between the lagoons, ranging between 0.97 and $48.9 \mathrm{mg} / \mathrm{m}^{3}$ (average value of $12.86 \mathrm{mg} / \mathrm{m}^{3}$ ) in Mundaú lagoon, and between 5.99 and $117.54 \mathrm{mg} / \mathrm{m}^{3}$ in Manguaba lagoon (average value of $42.77 \mathrm{mg} / \mathrm{m}^{3}$ ). In contrast to the Chl-a concentrations, the TSS concentrations were higher in Mundaú lagoon (range of 15.2-61.0 mg/L and average of $32.8 \mathrm{mg} / \mathrm{L}$ ) in comparison with Manguaba lagoon (range of $9.0-44.0 \mathrm{mg} / \mathrm{L}$ and average of $22.7 \mathrm{mg} / \mathrm{L}$ ). In addition, we did not find a strong correlation between the chlorophyll-a and TSS concentrations in the MMELS $\left(r^{2}=0.08\right.$; data not shown).

Table 3. Statistics of water constituents considering different subsets.

\begin{tabular}{ccccccccc}
\hline \multirow{2}{*}{ Subset } & \multicolumn{3}{c}{ Chlorophyll-a $\left(\mathbf{m g} / \mathbf{m}^{\mathbf{3}}\right)$} & \multicolumn{4}{c}{ SST $(\mathrm{mg} / \mathrm{L})$} \\
\cline { 2 - 9 } & Min & Max & Mean & Stdev & Min & Max & Mean & SD \\
\hline Mundaú $(\mathrm{N}=36)$ & 0.97 & 48.90 & 12.86 & 9.72 & 15.15 & 61.00 & 32.80 & 11.99 \\
Manguaba $(\mathrm{N}=36)$ & 5.99 & 117.54 & 42.77 & 24.22 & 9.00 & 44.00 & 22.86 & 9.34 \\
MMELS (N = 72) & 0.97 & 117.54 & 27.81 & 23.72 & 9.00 & 61.00 & 27.83 & 11.79 \\
\hline
\end{tabular}

\subsection{Reflectance Spectra and Classification}

The measured reflectance spectra (range of 400-720 nm) of the surveyed sampling points in the Mundaú and Manguaba lagoons are shown in Figure 2a,b, respectively. The hyperspectral reflectance differed slightly between the two datasets. Nevertheless, in both lagoons, it was possible to identify spectral features similar to reflectance spectra previously observed for turbid, productive waters [32,59], such as a slight depression at $440 \mathrm{~nm}$; a prominent peak around $565 \mathrm{~nm}$; a trough at $625 \mathrm{~nm}$ (more intense in Manguaba lagoon) followed by a discrete peak around $660 \mathrm{~nm}$; and a prominent trough at $670 \mathrm{~nm}$ followed by a prominent peak close to $705 \mathrm{~nm}$. With respect to Manguaba lagoon, we observed that the reflectance magnitude peak around $705 \mathrm{~nm}$ was comparable to that in the green region, except for the 14 July campaign, where we did not observe a well-defined peak in the green region.

Minimum reflectance values were observed around $670 \mathrm{~nm}$, where the maximum absorption of chlorophyll-a occurs in the red region. The minimum reflectance near $670 \mathrm{~nm}$ did not show a linear correlation with the chlorophyll-a concentration $\left(r^{2}=0.0006\right.$; data not shown), in contrast to the difference between peak reflectance around $700 \mathrm{~nm}$ and minimum reflectance near $670 \mathrm{~nm}\left(r^{2}=0.69\right.$, Figure 2c). In addition, we found a strong relationship between the peak position in the red region and the chlorophyll-a concentration $\left(r^{2}=0.8\right.$, Figure $2 \mathrm{~d}$ ) but a very poor correlation between maximum reflectance values near $700 \mathrm{~nm}$ and chlorophyll-a $\left(r^{2}=0.1\right.$; data not shown).

Clustering analyses resulted in four classes of normalized reflectance, which were sufficient to explain the spatial or temporal dependencies in the remote sensing reflectance data over the entire system (Figure 3). The behavior of the mean and standard deviation in the spectra of the four classes can be observed in Figure 4. A comprehensive description of each group is presented below. 

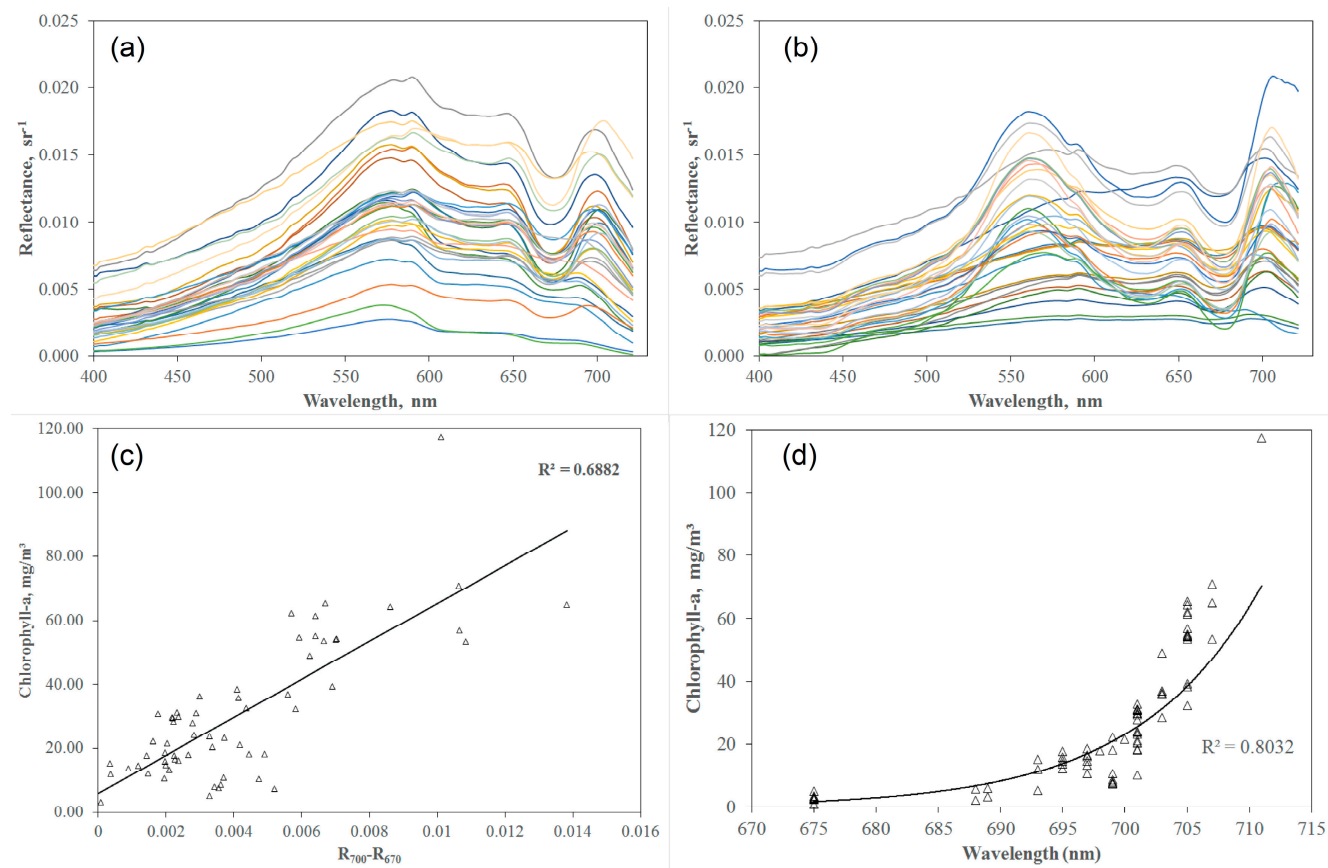

Figure 2. Typical spectral profiles in the MMELS waters measured in 2015: (a) Mundaú (5 May, 10 June, and 8 August); and (b) Manguaba (14 July, 3 September, and 22 September). Each line represents the spectral reflectance measured at a certain sampling point. The following relationships are also presented: (c) chlorophyll-a concentration versus the difference between the peak reflectance around $700 \mathrm{~nm}$ and the minimum reflectance near $670 \mathrm{~nm}$; (d) and the chlorophyll-a concentration versus the peak position in the red region.

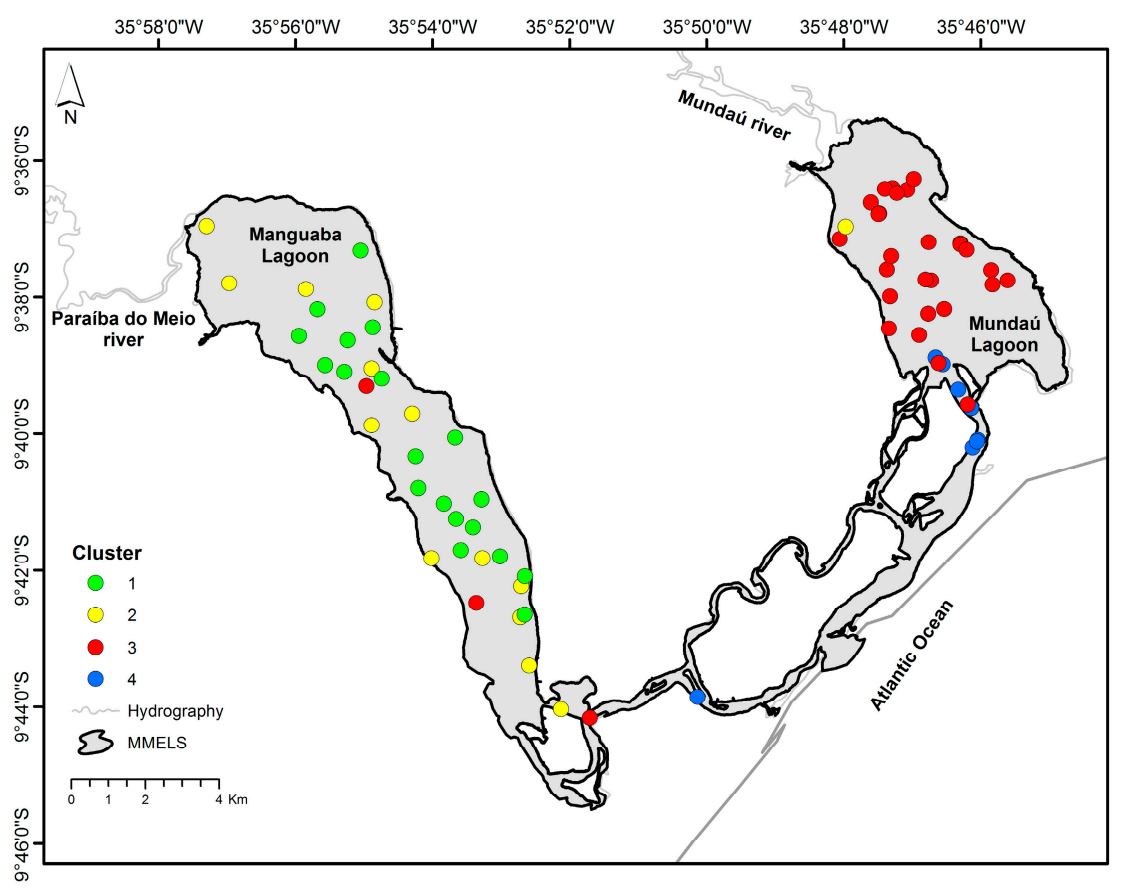

Figure 3. Reflectance spectra k-means clustering classification for normalized data in MMELS. 
Class $1(\mathrm{~N}=19)$

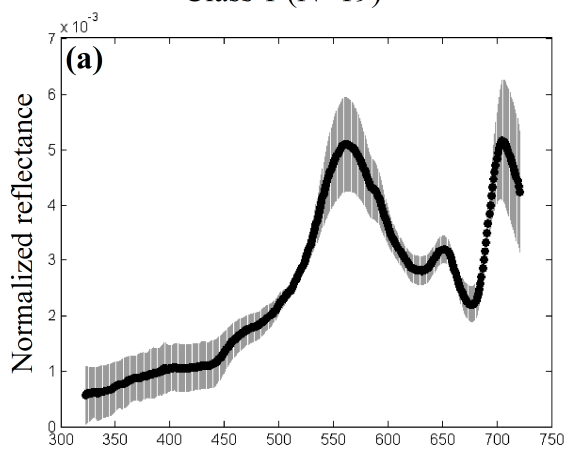

Wavelength, nm

Class $3(\mathrm{~N}=31)$

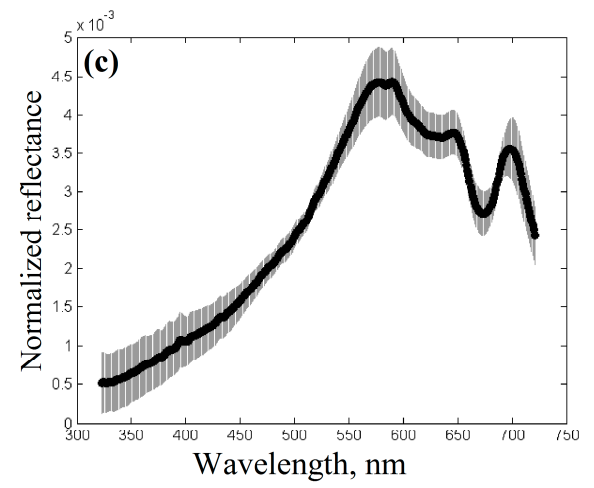

Class $2(\mathrm{~N}=14)$

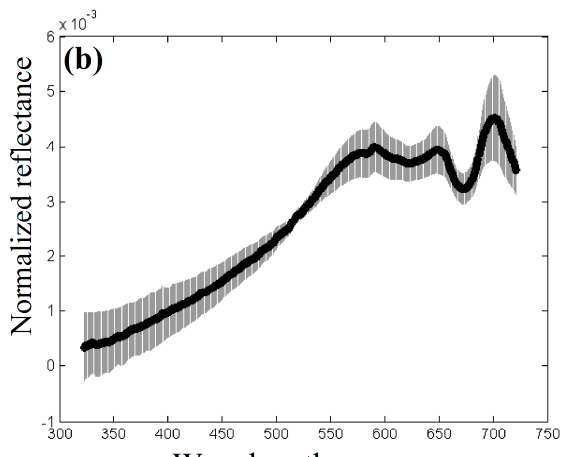

Wavelength, nm

Class $4(\mathrm{~N}=8)$

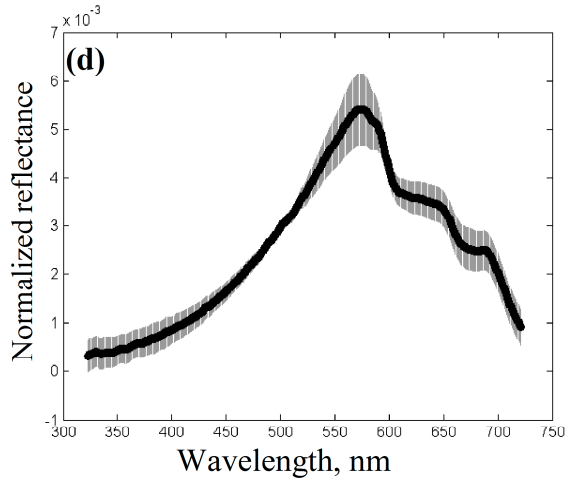

Figure 4. Mean (black dots) and standard deviation (grey ranges) for four classes of the normalized reflectance spectra: (a) Class 1; (b) Class 2; (c) Class 3; and (d) Class 4.

Class 1 (Figure 4a) consisted only of sampling stations in the Manguaba lagoon $(\mathrm{N}=19)$. This class was characterized by a slight depression at around $440 \mathrm{~nm}$ followed by two well-marked troughs at 625 and $675 \mathrm{~nm}$. Two distinct peaks with comparable magnitudes at around 560 and $710 \mathrm{~nm}$ were also well pronounced. This class had the highest chlorophyll-a concentrations and the lowest TSS concentrations with average values of approximately $56.40 \mathrm{mg} / \mathrm{m}^{3}$ and $21.50 \mathrm{mg} / \mathrm{m}^{3}$, respectively.

Class 2 (Figure 4b) contained all 12 samples collected during the 14 July campaign in Manguaba lagoon and only one sample located closest to the main river of the Mundaú lagoon $(\mathrm{N}=14)$. This class was characterized by an indistinct peak in the green region, a strong trough at $675 \mathrm{~nm}$ and a peak at around $700 \mathrm{~nm}$. This class had moderate values of chlorophyll-a and TSS, with average values of approximately $27.60 \mathrm{mg} / \mathrm{m}^{3}$ and $24.00 \mathrm{mg} / \mathrm{m}^{3}$, respectively.

Class 3 (Figure 4c) mainly represented the vast majority of the Mundaú lagoon waters and a few samples that were spatially distributed in the Manguaba lagoon $(\mathrm{N}=31)$. This class was characterized by a clearly defined trough at $675 \mathrm{~nm}$ and a distinct peak around $700 \mathrm{~nm}$. The chlorophyll-a concentrations were lower than those observed in Class 2, with average and maximum values of $14.87 \mathrm{mg} / \mathrm{m}^{3}$ and $32.64 \mathrm{mg} / \mathrm{m}^{3}$, respectively. This class also had the highest TSS concentrations with average values of approximately $34.00 \mathrm{mg} / \mathrm{m}^{3}$.

Class 4 (Figure $4 \mathrm{~d}$ ) consisted of points located near the channels connecting the lagoons to the ocean $(\mathrm{N}=8)$. This class showed no specific spectral features and was characterized by the lowest chlorophyll-a concentrations (average of $3.3 \mathrm{mg} / \mathrm{m}^{3}$ ) and moderate TSS concentrations (average of $\left.25.90 \mathrm{mg} / \mathrm{m}^{3}\right)$. 


\subsection{Assessment of Chl-a Retrieval Models}

A summary of the accuracy assessment of the best band models for classified and non-classified waters-considering three distinct datasets (i.e., Mundaú lagoon, Manguaba lagoon and MMELS)—can be observed in Table 4.

Table 4. Slopes (p) and intercepts ( $\mathrm{q}$ ) of the linear best-fit function between observed and retrieved chlorophyll-a with corresponding coefficient of determination $\left(r^{2}\right)$ and root mean square error (RMSE in $\mathrm{mg} / \mathrm{m}^{3}$ ) for the monitoring datasets. The MMELS dataset (global) was divided into calibration (cal) and independent validation (val) subsets to evaluate the accuracy and stability of the best models based on the reflectance measurements.

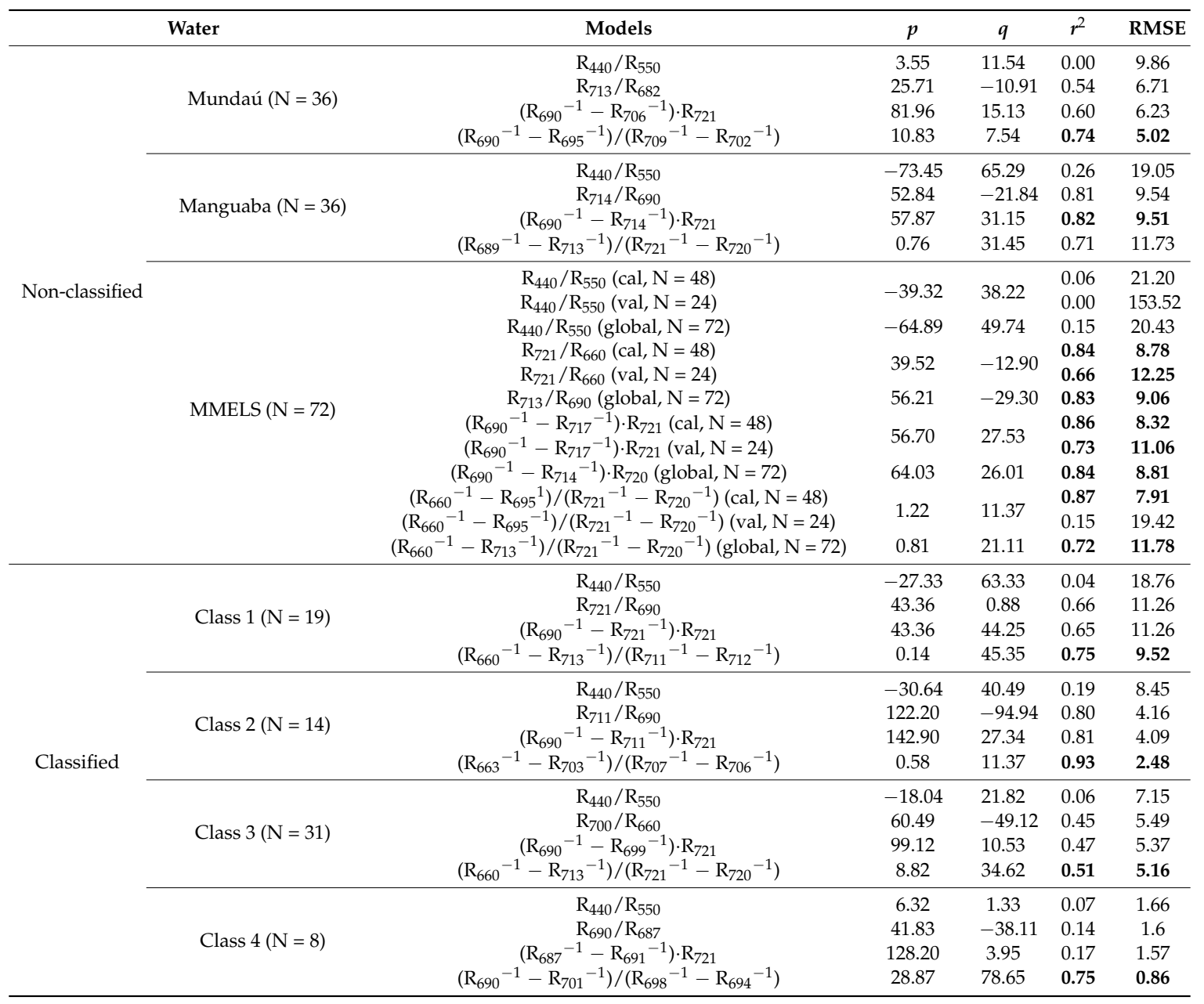

For non-classified waters, the blue-green ratio model Equation (5) showed a very poor correlation with the measured Chl-a concentration for the MMELS dataset $\left(r^{2}=0.06\right.$ and 0.00 for calibration and validation subsets, respectively), as well as for each lagoon $\left(r^{2}<0.27\right)$. The NIR-Red band models and the two-, three- and four-band models had similar performance considering the calibration subset, with strong coefficients of determination for the whole system $\left(r^{2}>0.84\right)$. These models also showed a good performance for Manguaba lagoon $\left(r^{2}>0.81\right)$. A more accurate and stable Chl-a retrieval was obtained using a three-band model for MMELS, with optimal spectral band positions for $\lambda_{1}, \lambda_{2}$ and $\lambda_{3}$ at 690,717 and $721 \mathrm{~nm}$, respectively, which was followed by a two-band model for MMELS with wavelengths $\lambda_{1}$ and $\lambda_{2}$ equal to 660 and $721 \mathrm{~nm}$, respectively. Moreover, a remarkable decrease in performance of the four-band model was observed for the validation subset, suggesting an unstable Chl-a retrieval using this model. For Manguaba lagoon, the four-band model did not perform better 
than the three-band model, in contrast to Mundaú lagoon, where an improvement in performance was observed with an increase in model complexity (i.e., from the two-band to the four-band model).

An improvement in performance with increasing model complexity was also observed for classified waters. In general, the two- and three-band models for classified waters did not improve chlorophyll-a retrieval in comparison with band models for non-classified waters. However, the four-band model for Class 2 showed the best performance $\left(r^{2}=0.93\right.$, RMSE $\left.=2.48 \mathrm{mg} / \mathrm{m}^{3}\right)$ among all models for both classified and non-classified waters, with optimal spectral band positions for $\lambda_{1}, \lambda_{2}, \lambda_{3}$ and $\lambda_{4}$ at 663, 703, 706 and $707 \mathrm{~nm}$, respectively. Strong linear relationships between the four-band model and the measured Chl-a were established for Class $1\left(r^{2}=0.75\right.$, RMSE $\left.=9.52 \mathrm{mg} / \mathrm{m}^{3}\right)$ and Class $4\left(r^{2}=0.75\right.$, RMSE $\left.=0.86 \mathrm{mg} / \mathrm{m}^{3}\right)$. For Class 3, the four-band model also showed a reasonable performance $\left(r^{2}=0.51\right.$, RMSE $\left.=5.16 \mathrm{mg} / \mathrm{m}^{3}\right)$ but was still lower than the band model for Mundaú lagoon (non-classified waters).

\subsection{Retrieval of Chlorophyll-a Using Models Based on Simulated Satellite Bands}

The applicability of satellite sensors such as MODIS, MERIS, OLCI and MSI was evaluated considering two- and three-band models for MMELS and the four-band model for Class 2 since these models showed the best performance with respect to chlorophyll-a retrieval using reflectance measurements.

The accuracy assessment of the best band models for the MMELS and Class 2 waters with respect to the four satellite sensors can be observed in Table 5. Notably, the two-band models showed better performance compared with the other models based on simulated satellite bands for MMELS and Manguaba lagoon. Considering the operating range, it was not possible to find a good combination of MODIS data, which resulted in the lower performance of this sensor among the two-band models. For both the MERIS and OLCI sensors, $\lambda_{2}$ was represented by the 9th channel (centered at $709 \mathrm{~nm}$ ), and $\lambda_{1}$ was repositioned to the 8 th channel (centered at $681 \mathrm{~nm}$ ). However, the best performance of the MERIS and OLCI sensors was observed with greater displacement of $\lambda_{1}$ to the 7th channel (centered at $665 \mathrm{~nm}$ ). In addition, a good model performance was also obtained using simulated MSI bands $\left(R_{705} / R_{665}\right)$. For Class 2 waters, the four-band model could not be applied for Chl-a estimation using satellite sensors, in contrast to the four-band model based on $R_{r s}$ measured in-situ. However, it was possible to accurately retrieve Chl-a using the three-band model for the MERIS and OLCI sensor data.

Table 5. Slopes (p) and intercepts (q) of the linear best-fit function between observed and retrieved chlorophyll-a with corresponding coefficient of determination $\left(r^{2}\right)$ and root mean square error (RMSE in $\mathrm{mg} / \mathrm{m}^{3}$ ) for various satellite bands.

\begin{tabular}{cccccc}
\hline Water & Models & $p$ & $q$ & $r^{2}$ & RMSE \\
\hline & MODIS $-\mathrm{R}_{645} / \mathrm{R}_{555}$ & 38.21 & -11.32 & 0.56 & 14.55 \\
& MERIS $-\mathrm{R}_{709} / \mathrm{R}_{681}$ & 19.08 & 7.27 & 0.64 & 13.29 \\
Manguaba $(\mathrm{N}=36)$ & 19.97 & 6.51 & 0.65 & 13.07 \\
& OLCI $-\mathrm{R}_{709} / \mathrm{R}_{681}$ & 29.78 & -6.35 & $\mathbf{0 . 7 2}$ & $\mathbf{1 1 . 7 6}$ \\
& MERIS $-\mathrm{R}_{709} / \mathrm{R}_{665}$ & 28.43 & -4.53 & $\mathbf{0 . 7 1}$ & $\mathbf{1 1 . 8 7}$ \\
& OLCI $-\mathrm{R}_{709} / \mathrm{R}_{665}$ & 34.39 & -12.52 & $\mathbf{0 . 7 2}$ & $\mathbf{1 1 . 7 3}$ \\
& MSI $-\mathrm{R}_{705} / \mathrm{R}_{665}$ & 58.77 & 18.98 & $\mathbf{0 . 7 1}$ & $\mathbf{1 1 . 8 4}$ \\
& MERIS $-\left(\mathrm{R}_{681}-1-\mathrm{R}_{709}-1\right) \cdot \mathrm{R}_{665}$ & 73.60 & 18.97 & $\mathbf{0 . 7 0}$ & $\mathbf{1 2 . 1 1}$ \\
\hline & OLCI $-\left(\mathrm{R}_{681}-1-\mathrm{R}_{709}-1\right) \cdot \mathrm{R}_{674}$ & 34.63 & -17.27 & 0.31 & 18.42 \\
& MODIS $-\mathrm{R}_{645} / \mathrm{R}_{555}$ & 23.98 & -6.73 & 0.70 & 12.12 \\
MMELS $(\mathrm{N}=72)$ & MERIS $-\mathrm{R}_{709} / \mathrm{R}_{681}$ & 24.95 & -7.25 & 0.71 & 11.91 \\
& OLCI $-\mathrm{R}_{709} / \mathrm{R}_{681}$ & 34.12 & -17.29 & $\mathbf{0 . 7 7}$ & $\mathbf{1 0 . 6 6}$ \\
& MERIS $-\mathrm{R}_{709} / \mathrm{R}_{665}$ & 32.83 & -15.74 & $\mathbf{0 . 7 6}$ & $\mathbf{1 0 . 7 7}$ \\
& OLCI $-\mathrm{R}_{709} / \mathrm{R}_{665}$ & 39.07 & -23.40 & $\mathbf{0 . 7 8}$ & $\mathbf{1 0 . 4 4}$ \\
& MSI $-\mathrm{R}_{705} / \mathrm{R}_{665}$ & 39.74 & 20.92 & 0.60 & 14.00 \\
& MERIS $-\left(\mathrm{R}_{681}-1-\mathrm{R}_{709}-1\right) \cdot \mathrm{R}_{665}$ & 42.17 & 22.74 & 0.55 & 14.87 \\
& OLCI $-\left(\mathrm{R}_{681}-1-\mathrm{R}_{709}{ }^{-1}\right) \cdot \mathrm{R}_{674}$ & 1.80 & 28.87 & 0.01 & 22.03 \\
& MERIS $-\left(\mathrm{R}_{665}{ }^{-1}-\mathrm{R}_{709}-1\right) /\left(\mathrm{R}_{709}-1-\mathrm{R}_{681}-1\right)$ & 0.67 & 27.84 & 0.00 & 22.15 \\
\hline
\end{tabular}


Table 5. Cont.

\begin{tabular}{cccccc}
\hline Water & Models & $p$ & $\boldsymbol{q}$ & $\boldsymbol{r}^{2}$ & RMSE \\
\hline & MODIS $-\mathrm{R}_{645} / \mathrm{R}_{555}$ & 18.12 & 10.48 & 0.02 & 9.30 \\
& MERIS $-\mathrm{R}_{709} / \mathrm{R}_{681}$ & 44.75 & -28.22 & 0.65 & 5.58 \\
CLCI $-\mathrm{R}_{709} / \mathrm{R}_{681}$ & 48.42 & -31.57 & 0.67 & 5.42 \\
& MSI $-\mathrm{R}_{705} / \mathrm{R}_{665}$ & 45.14 & -28.87 & 0.53 & 6.39 \\
& $\mathrm{~N}=14)$ & 71.65 & 14.33 & $\mathbf{0 . 7 0}$ & $\mathbf{5 . 1 5}$ \\
& MERIS $-\left(\mathrm{R}_{681}-1-\mathrm{R}_{709}-1\right) \cdot \mathrm{R}_{665}$ & 81.47 & 14.78 & $\mathbf{0 . 7 1}$ & $\mathbf{5 . 0 2}$ \\
& OLCI $-\left(\mathrm{R}_{681}-1-\mathrm{R}_{709}-1\right) \cdot \mathrm{R}_{674}$ & -6.15 & 22.77 & 0.28 & 7.95 \\
& MERIS $-\left(\mathrm{R}_{665}{ }^{-1}-\mathrm{R}_{709}-1\right) /\left(\mathrm{R}_{709}-1-\mathrm{R}_{681}-1\right)$ & -6.33 & 7.69 \\
\hline
\end{tabular}

\section{Discussion}

MMELS can be characterized as an optically complex environment (Case 2 water) since a low correlation between TSS and Chl-a was found $\left(r^{2}=0.08\right)$. This result suggests that these constituents do not necessarily covary over space and time, in contrast to oligotrophic and clear waters $[24,60]$. Furthermore, the high turbidity observed in the lagoons, with Secchi disk values ranging between $0.58 \mathrm{~m}$ and $0.95 \mathrm{~m}$ (see [61]), suggests a low or nonexistent effect of the bottom sediment on the spectral reflectance since the depth of the photic zone (light penetration zone) is lower than the water depth in MMELS (see Table 1).

The low reflectance values in the blue region (from $400 \mathrm{~nm}$ to around $470 \mathrm{~nm}$ ) indicate the presence of yellow substances, which usually dominate the absorption in this spectral range for waters influenced by river runoff [62], suggesting a significant CDOM contribution from the rivers discharging to both lagoons. The slight depression observed around $440 \mathrm{~nm}$ can be explained by absorption peaks of chlorophyll-a in this region.

The first reflectance peak in the green range, around $560 \mathrm{~nm}$ in Mundaú lagoon and $570 \mathrm{~nm}$ in Manguaba lagoon, indicates minimal absorption by most algal pigments, but this reflectance is still influenced by CDOM absorption [63]. Thus, the backscattering by inorganic suspended matter and phytoplankton predominates in determining the spectral reflectance.

The minimum, observed around $625 \mathrm{~nm}$, is related to phycocyanin absorption due to the presence of cyanobacteria $[34,64,65]$. In Manguaba lagoon, this feature was more prominent than in Mundaú lagoon, which may be explained by two factors: (a) the backscattering caused by the high TSS concentration in Mundaú lagoon may have masked the effect of phycocyanin absorption; and/or (b) the biomass of cyanobacteria was relatively low in Mundaú lagoon. The maximum absorption peak of chlorophyll-a in the red region, around $670 \mathrm{~nm}$ [39], was present in almost all reflectance spectra. It is likely that at this wavelength, the reflectance is still influenced by other optically active components since a weak correlation was observed between minimum reflectance near $670 \mathrm{~nm}$ and the chlorophyll-a concentration $\left(r^{2}=0.0006\right)$.

The second prominent reflectance peak around $700 \mathrm{~nm}$ occurred because of minimal absorption of water constituents (Chl-a, NAP, and CDOM) and particulate backscattering, which controls the reflectance variations in this region. Although the peak magnitude near $700 \mathrm{~nm}$ vs. the Chl-a concentration indicated a very poor relationship $\left(r^{2}=0.1\right)$, the increase in the Chl-a concentration caused the displacement of the peak position in the red region $\left(r^{2}=0.8\right.$, Figure 2d), which is usually observed in turbid and productive waters $[33,45,57,66]$. Indeed, the peak positions near $700 \mathrm{~nm}$ in Manguaba lagoon occurred at wavelengths slightly longer than those in Mundaú lagoon, which exhibited lower concentrations of chlorophyll-a.

The optical classes resulting from the clustering analysis indicated a homogeneous spatial behavior over Manguaba lagoon for two distinct classes related to the wet (Class 2) and dry (Class 1) seasons. Water samples associated with Class 2 showed optical characteristics of waters dominated by chlorophyll-a and suspended sediment, which exhibited higher concentrations due to the increase in sediment loading from river discharge in the wet season. In addition, the combined effect of increasing light availability (i.e., fewer suspended sediments) and higher water temperature can 
explain the distinct optical behavior associated with waters dominated by chlorophyll-a observed in the dry season.

The water samples from the Mundaú lagoon were mostly classified as Class 3, indicating the homogeneity of the optical properties of these waters. This optical class had intermediate concentrations of chlorophyll-a and higher concentrations of TSS, which can be explained by the following: (a) higher nutrient and organic matter loading in Mundaú lagoon in comparison with Manguaba lagoon, since a considerable amount of sewage from surrounding municipalities, mainly Maceió city, is regularly discharged into Mundaú lagoon; and (b) more intensive anthropogenic activities (i.e., agriculture and dredging along the river-bed) in the Mundaú river basin, which favor soil erosion and sediment transport into Mundaú lagoon.

Regarding the evaluated models for non-classified waters, the blue-green ratio model was not a good algorithm to estimate the chlorophyll-a concentration for MMELS or the individual lagoons. As previously reported, this model is not suitable for turbid and productive waters (Case 2 water body) since reflectance in the blue and green ranges is strongly influenced by NAP and CDOM absorption, as well as by backscattering caused by inorganic and non-living organic suspended matter [63,67].

More accurate retrievals of chlorophyll-a were found using the NIR-Red band models. The twoand three-band NIR-Red models for Manguaba lagoon and MMELS had high coefficients of determination $\left(r^{2}>0.80\right)$ and similar performance with respect to other chlorophyll-a retrievals reported for turbid and productive estuaries [45]. The inclusion of the third band did not result in a significant improvement in performance relative to the two-band NIR-Red model, possibly because the effect of absorption by CDOM and NAP on reflectance was not relevant for the wavelengths chosen as optimal in Manguaba lagoon $\left(\lambda_{1}=690 \mathrm{~nm}, \lambda_{2}=714 \mathrm{~nm}\right)$ and MMELS $\left(\lambda_{1}=660 \mathrm{~nm}, \lambda_{2}=721 \mathrm{~nm}\right)$.

Despite the better performance of the three-band NIR-Red model, the optimal position for $\lambda_{3}$ was found in the upper limit of the operating range. At this wavelength, the reflectance was still high (e.g., $R_{721}>R_{670}$ was observed in some reflectance curves for both lagoons). This finding suggests that the absorption caused by pure water was not completely dominant in this region, and hence this reflectance was strongly influenced by the absorption and backscattering of the other water constituents. In general, values greater than $720 \mathrm{~nm}$ are usually found for $\lambda_{3}$ for three-band NIR-Red models applied to inland and coastal waters [33,37,44]. Therefore, it is likely that the spectral range of operation may have limited the displacement of $\lambda_{3}$ for higher NIR wavelengths.

Considering the four-band NIR-Red model applied to MMELS and Manguaba lagoon, the addition of the fourth band did not improve model's performance with respect to chlorophyll-a retrieval in comparison to the two- and three-band NIR-Red models. Interestingly, for both of these datasets, the optimal positions for $\lambda_{3}$ and $\lambda_{4}$ were close to the upper limit of the operating range. In addition, the distance between these two wavelengths was only $1 \mathrm{~nm}$, which is considerably smaller than the resolution of the radiometers used in the study. Naturally, such positioning aimed to minimize the effect of absorption by CDOM and NAP, as well as backscattering, in $\lambda_{3}$, but clearly this was not sufficient, especially for Manguaba lagoon water samples with higher concentrations of chlorophyll-a. This resulted in a decrease in performance of the four-band model in relation to the three-band model. In general, optimal values of $\lambda_{4}$ are found around $730 \mathrm{~nm}[38,44]$, which are beyond the spectral range of operation of this study.

The same pattern was not observed in Mundaú lagoon, where an increase in model complexity (i.e., from the two to the four-band NIR-Red model) resulted in an improvement of chlorophyll-a retrieval. However, the best model for Mundaú lagoon (four-band NIR-Red model, $r^{2}=0.74$ ) had a lower performance in relation to the two- and three-band NIR-Red models applied to both MMELS and Manguaba lagoon. The work in [33] reported that in turbid waters, two-band NIR-Red models tend to overestimate chlorophyll-a due to an increase in reflectance caused by backscattering of the huge amount of suspended particles in both the visible and NIR ranges. Thus, a lower ability to estimate chlorophyll-a in Mundaú lagoon was expected since this lagoon can be considered a highly turbid system that is less productive than Manguaba lagoon, as most water samples exhibit chlorophyll-a 
concentrations less than $25 \mathrm{mg} / \mathrm{m}^{3}$. In these environments, the absorption coefficient of chlorophyll-a may be comparable, in terms of magnitude, to either the backscattering coefficient of suspended particles or the absorption coefficient of NAP and CDOM, not satisfying the condition assumed for NIR-Red models (i.e., $a_{\text {chl- } a}\left(\lambda_{1}\right)>>a_{N A P}\left(\lambda_{1}\right)+a_{C D O M}\left(\lambda_{1}\right)$ and $\left.a_{c h l-a}\left(\lambda_{1}\right)>>b_{b}\left(\lambda_{1}\right)\right)$. Furthermore, the high concentration of TSS in Mundaú lagoon favored the four-band NIR-Red model since this algorithm minimizes the effect of absorption by CDOM and NAP in NIR wavelengths [36]. Nevertheless, it may be possible to improve the performance of the four-band NIR-Red model in Mundaú lagoon by searching for optimal values of $\lambda_{4}$ beyond the upper limit of the spectral range of operation (i.e., for $\lambda_{4}>721 \mathrm{~nm}$ ). For instance, it is common to find optimal values of $\lambda_{4}$ around $740 \mathrm{~nm}$ [36].

Regarding the evaluated models for classified waters, the inversion algorithms applied to homogeneous groups generally did not improve the chlorophyll-a retrieval in comparison with the band models using the non-classified dataset; this may be associated with the following: (a) the derivation of models from a reduced number of water samples in each class; (b) the classification method chosen (e.g., unsupervised classification clustering, fuzzy logic classification and reflectance shape characteristics calculation approach), which may control the number and optical characteristics of each class [38,54,55]; and (c) a higher uniformity of both optical characteristics and concentration values of the water constituents in each class, which may result in a lower performance of the models, mainly for classes with higher concentrations of suspended matter and lower concentrations of chlorophyll-a. However, the pre-classification of the reflectance spectra dataset into homogeneous groups has shown to be satisfactory to validate the band models using a different handheld dataset without repositioning of optimal wavelength values for each model $[38,48]$. Therefore, the classified band models obtained for Manguaba lagoon can be considered promising, especially the model for Class 2.

Although estuarine environments have more intensified dynamics in relation to other inland water bodies (i.e., lakes and reservoirs), the high retention times of both the Mundaú (>2 weeks) and Manguaba (>1 month) lagoons suggest slight water quality changes over time. Thus, MMELS demonstrates considerable potential for the application of models using satellite sensors with spatial and temporal resolutions less than $500 \mathrm{~m}$ and one week, respectively, similar to the sensors evaluated in this study. In general, the two-band models based on simulated satellite bands showed better performance than the three-band models for MMELS, which is in agreement with other studies [37,44,48]. The results also indicate that the two-band model using the MODIS sensor $\left(R_{645} / R_{555}\right)$ failed to estimate chlorophyll-a. This likely occurred because it was not possible to use band 15 (centered at $748 \mathrm{~nm}$ ), which is widely used in band models based on MODIS spectral bands [32,33,37] but is still beyond the spectral range of operation of this study. Nevertheless, enhanced chlorophyll-a retrievals have been found using a two-band algorithm based on simulated Sentinel-2/MSI, Envisat/MERIS and Sentinel-3/OLCI satellite bands, indicating a promising application of these sensors in MMELS and Manguaba lagoon. Regarding Class 2 waters, a decrease in performance of the four-band model based on simulated MERIS and OLCI bands in comparison with the two- and three-band models can be explained by the inability to identify a good combination of simulated satellite bands near the wavelengths chosen as optimal for the models using $R_{r s}$ measured in-situ. The assessment of models to directly estimate chlorophyll-a using satellite images captured by the MSI and OLCI sensors encourages further future investigation in MMELS, since images from these recently spaceborne sensors were not available during the monitoring period (May to September 2015). Despite the spectral range operational constraints, our findings suggest that empirical models based on optical properties involving water constituents have a strong potential to estimate chlorophyll-a using spectral data from satellite, airborne or handheld sensors in productive tropical estuaries, as was also observed in temperate, tropical and subtropical inland waters $[14,30,33,68]$.

Despite the wide range of measured chlorophyll-a in the dataset $\left(0.97-117.24 \mathrm{mg} \cdot \mathrm{m}^{-3}\right)$, the monitoring period was limited from May to September 2015, which corresponds to an inter-seasonal period between the end of the wet season and the beginning of the dry season. A recent study, 
using approximately 100 water samples for each season, indicated that a unique model based on spectral reflectance can be used to estimate chlorophyll-a for all four seasons [42], suggesting that the empirical models described in this study can also be applied outside of the monitoring period.

\section{Conclusions}

In this study, we examined the performance of several algorithms based on spectral bands to estimate chlorophyll-a in a shallow, turbid, productive tropical estuarine-lagoon system using in situ reflectance spectra. We also investigated the potential of model application using satellite sensors. Our results showed accurate retrievals of chlorophyll-a $\left(r^{2}>0.80\right)$ using the NIR-Red three-band model for MMELS, which exhibits a light penetration zone lower than the water depth due to high turbidity. These accurate models open up a novel branch for scientific investigations searching for new spectral reflectance-based models using in situ reflectance measurements beyond the spectral range of operation in this study. In addition, these models can be used to explore the possibility of extending this approach to other productive tropical estuaries.

We also observed accurate chlorophyll-a retrievals using the two-band algorithm based on the simulated Sentinel-2/MSI, Envisat/MERIS and Sentinel-3/OLCI satellite bands with temporal and spatial resolutions less than one week and $500 \mathrm{~m}$, respectively, indicating a promising application of these sensors to remotely estimate chlorophyll-a in MMELS and Manguaba lagoon. However, further validation to test the application of these sensors must be addressed considering the characteristics of each sensor, in particular, the signal-to-noise ratio and radiometric and spatial resolutions.

Acknowledgments: We are grateful to institutional grants provided by the Agency for Financing Studies and Projects (Finep), research project No. 01.13.0419.00, and The Brazilian National Council for Scientific and Technological Development (CNPq), through the Universal Research Project (476789/2013-3), which funded all equipment and operating expenses of this study. We also thank the Research Support Foundation of the State of Pernambuco (FACEPE), who granted a doctoral scholarship (PBPG-1148-3.01/12) to the first author, and IMA/AL, who provided the boat that was used for collecting the in situ data. The authors would also like to thank the anonymous referees, who helped to significantly improve the quality and the clarity of this manuscript.

Author Contributions: R.C.L., J.-M.M., J.A.C. and C.R.F.Jr. developed the idea for the study, as well as its design. R.C.L., D.d.M.M. and C.R.F.Jr. were responsible for the construction and validation of the dataset. R.C.L., J.-M.M., J.A.C., D.d.M.M. and C.R.F.Jr. participated in the analysis and development of the discussion. R.C.L. and C.R.F.Jr. finalized the manuscript. All authors read and approved the manuscript.

Conflicts of Interest: The authors declare no conflict of interest.

\section{References}

1. Mitchell, S.B.; Jennerjahn, T.C.; Vizzini, S.; Zhang, W. Changes to processes in estuaries and coastal waters due to intense multiple pressures-An introduction and synthesis. Estuar. Coast. Shelf Sci. 2015, 156, 1-6. [CrossRef]

2. Hardisty, J. Introduction to estuarine systems. In Estuaries: Monitoring and Modeling the Physical System; Blackwell Publishing: Hoboken, NJ, USA, 2007; pp. 3-22.

3. Cadee, G.C. Book review: Nutrients and eutrophication in estuaries and coastal waters. Aquat. Ecol. 2004, 38, 616-617. [CrossRef]

4. Boyer, J.N.; Kelble, C.R.; Ortner, P.B.; Rudnick, D.T. Phytoplankton bloom status: Chlorophyll a biomass as an indicator of water quality condition in the southern estuaries of florida, USA. Ecol. Indic. 2009, 9, S56-S67. [CrossRef]

5. Scanes, P.; Coade, G.; Doherty, M.; Hill, R. Evaluation of the utility of water quality based indicators of estuarine lagoon condition in nsw, australia. Estuar. Coast. Shelf Sci. 2007, 74, 306-319. [CrossRef]

6. Paerl, H.W.; Valdes-Weaver, L.M.; Joyner, A.R.; Winkelmann, V. Phytoplankton indicators of ecological change in the eutrophying pamlico sound system, north carolina. Ecol. Appl. 2007, 17, S88-S101. [CrossRef]

7. Navalgund, R.R.; Jayaraman, V.; Roy, P.S. Remote sensing applications: An overview. Curr. Sci. 2007, 93, 1747-1766. 
8. Bukata, R.P. Retrospection and introspection on remote sensing of inland water quality: "Like déjà vu all over again". J. Great Lakes Res. 2013, 39, 2-5. [CrossRef]

9. Odermatt, D.; Gitelson, A.; Brando, V.E.; Schaepman, M. Review of constituent retrieval in optically deep and complex waters from satellite imagery. Remote Sens. Environ. 2012, 118, 116-126. [CrossRef]

10. Tyler, A.N.; Hunter, P.D.; Spyrakos, E.; Groom, S.; Constantinescu, A.M.; Kitchen, J. Developments in earth observation for the assessment and monitoring of inland, transitional, coastal and shelf-sea waters. Sci. Total Environ. 2016, 572, 1307-1321. [CrossRef] [PubMed]

11. Cannizzaro, J.P.; Carder, K.L. Estimating chlorophyll a concentrations from remote-sensing reflectance in optically shallow waters. Remote Sens. Environ. 2006, 101, 13-24. [CrossRef]

12. Palmer, S.C.J.; Kutser, T.; Hunter, P.D. Remote sensing of inland waters: Challenges, progress and future directions. Remote Sens. Environ. 2015, 157, 1-8. [CrossRef]

13. Mouw, C.B.; Greb, S.; Aurin, D.; DiGiacomo, P.M.; Lee, Z.; Twardowski, M.; Binding, C.; Hu, C.; Ma, R.; Moore, T.; et al. Aquatic color radiometry remote sensing of coastal and inland waters: Challenges and recommendations for future satellite missions. Remote Sens. Environ. 2015, 160, 15-30. [CrossRef]

14. Xie, C.-H.; Chang, J.-Y.; Zhang, Y.-Z. A new method for estimating chlorophyll-a concentration in the pearl river estuary. Optik 2015, 126, 4510-4515. [CrossRef]

15. Le, C.; Hu, C.; English, D.; Cannizzaro, J.; Chen, Z.; Kovach, C.; Anastasiou, C.J.; Zhao, J.; Carder, K.L. Inherent and apparent optical properties of the complex estuarine waters of tampa bay: What controls light? Estuar. Coast. Shelf Sci. 2013, 117, 54-69. [CrossRef]

16. Tzortziou, M.; Subramaniam, A.; Herman, J.R.; Gallegos, C.L.; Neale, P.J.; Harding, L.W., Jr. Remote sensing reflectance and inherent optical properties in the mid chesapeake bay. Estuar. Coast. Shelf Sci. 2007, 72, 16-32. [CrossRef]

17. Gons, H.J. Optical teledetection of chlorophyll a in turbid inland water. Environ. Sci. Technol. 1999, 33, 1127-1132. [CrossRef]

18. Preisendorfer, R.W. Application of Radiative Transfer Theory to Light Measurements in the Sea, Monograph No. 10; L'Institut Géographique National: Champigneulles, France, 1961.

19. Morel, A.; Gentili, B. Diffuse reflectance of oceanic waters: Its dependence on sun angle as influenced by the molecular scattering contribution. Appl. Opt. 1991, 30, 4427-4438. [CrossRef] [PubMed]

20. Morel, A.; Gentili, B. Diffuse reflectance of oceanic waters. II. Bidirectional aspects. Appl. Opt. 1993, 32, 6864-6879. [CrossRef] [PubMed]

21. Pope, R.M.; Fry, E.S. Absorption spectrum (380-700 nm) of pure water. II. Integrating cavity measurements. Appl. Opt. 1997, 36, 8710-8723. [CrossRef] [PubMed]

22. Smith, R.C.; Baker, K.S. Optical properties of the clearest natural waters (200-800 nm). Appl. Opt. 1981, 20, 177-184. [CrossRef] [PubMed]

23. Morel, A. Optical properties of pure water and pure sea water. In Optical Aspects of Oceanography; Jerlov, N.G., Nielsen, E.S., Eds.; Academic Press: New York, NY, USA, 1974; pp. 1-24.

24. Morel, A.; Prieur, L. Analysis of variations in ocean color1. Limnol. Oceanogr. 1977, 22, 709-722. [CrossRef]

25. Gordon, H.R.; Morel, A.Y. In-water algorithms. In Remote Assessment of Ocean Color for Interpretation of Satellite Visible Imagery; Springer: Berlin, Germany, 1983; pp. 24-67.

26. Hu, C.; Lee, Z.; Franz, B. Chlorophyll aalgorithms for oligotrophic oceans: A novel approach based on three-band reflectance difference. J. Geophys. Res. Oceans 2012, 117. [CrossRef]

27. O’Reilly, J.E.; Maritorena, S.; Mitchell, B.G.; Siegel, D.A.; Carder, K.L.; Garver, S.A.; Kahru, M.; McClain, C. Ocean color chlorophyll algorithms for seawifs. J. Geophys. Res. Oceans 1998, 103, 24937-24953. [CrossRef]

28. Harding, J.L.W.; Magnuson, A.; Mallonee, M.E. Seawifs retrievals of chlorophyll in chesapeake bay and the mid-atlantic bight. Estuar. Coast. Shelf Sci. 2005, 62, 75-94. [CrossRef]

29. Wang, M.; Shi, W.; Tang, J. Water property monitoring and assessment for china's inland lake taihu from MODIS-aqua measurements. Remote Sens. Environ. 2011, 115, 841-854. [CrossRef]

30. Le, C.; Hu, C.; English, D.; Cannizzaro, J.; Chen, Z.; Feng, L.; Boler, R.; Kovach, C. Towards a long-term chlorophyll-a data record in a turbid estuary using MODIS observations. Prog. Oceanogr. 2013, 109, 90-103. [CrossRef]

31. Dall'Olmo, G.; Gitelson, A.A.; Rundquist, D.C. Towards a unified approach for remote estimation of chlorophyll-a in both terrestrial vegetation and turbid productive waters. Geophys. Res. Lett. 2003, 30. [CrossRef] 
32. Dall'Olmo, G.; Gitelson, A.A.; Rundquist, D.C.; Leavitt, B.; Barrow, T.; Holz, J.C. Assessing the potential of seawifs and MODIS for estimating chlorophyll concentration in turbid productive waters using red and near-infrared bands. Remote Sens. Environ. 2005, 96, 176-187. [CrossRef]

33. Gitelson, A.A.; Dall'Olmo, G.; Moses, W.; Rundquist, D.C.; Barrow, T.; Fisher, T.R.; Gurlin, D.; Holz, J. A simple semi-analytical model for remote estimation of chlorophyll-a in turbid waters: Validation. Remote Sens. Environ. 2008, 112, 3582-3593. [CrossRef]

34. Randolph, K.; Wilson, J.; Tedesco, L.; Li, L.; Pascual, D.L.; Soyeux, E. Hyperspectral remote sensing of cyanobacteria in turbid productive water using optically active pigments, chlorophyll a and phycocyanin. Remote Sens. Environ. 2008, 112, 4009-4019. [CrossRef]

35. Chavula, G.; Brezonik, P.; Thenkabail, P.; Johnson, T.; Bauer, M. Estimating chlorophyll concentration in lake malawi from MODIS satellite imagery. Phys. Chem. Earth Parts A/B/C 2009, 34, 755-760. [CrossRef]

36. Le, C.; Li, Y.; Zha, Y.; Sun, D.; Huang, C.; Lu, H. A four-band semi-analytical model for estimating chlorophyll a in highly turbid lakes: The case of taihu lake, china. Remote Sens. Environ. 2009, 113, 1175-1182. [CrossRef]

37. Gurlin, D.; Gitelson, A.A.; Moses, W.J. Remote estimation of chl-a concentration in turbid productive waters-Return to a simple two-band nir-red model? Remote Sens. Environ. 2011, 115, 3479-3490. [CrossRef]

38. Le, C.; Li, Y.; Zha, Y.; Sun, D.; Huang, C.; Zhang, H. Remote estimation of chlorophyll a in optically complex waters based on optical classification. Remote Sens. Environ. 2011, 115, 725-737. [CrossRef]

39. Yacobi, Y.Z.; Moses, W.J.; Kaganovsky, S.; Sulimani, B.; Leavitt, B.C.; Gitelson, A.A. Nir-red reflectance-based algorithms for chlorophyll-A estimation in mesotrophic inland and coastal waters: Lake kinneret case study. Water Res. 2011, 45, 2428-2436. [CrossRef] [PubMed]

40. Lyu, H.; Li, X.; Wang, Y.; Jin, Q.; Cao, K.; Wang, Q.; Li, Y. Evaluation of chlorophyll-a retrieval algorithms based on MERIS bands for optically varying eutrophic inland lakes. Sci. Total Environ. 2015, 530-531, 373-382. [CrossRef] [PubMed]

41. Palmer, S.C.J.; Hunter, P.D.; Lankester, T.; Hubbard, S.; Spyrakos, E.; Tyler, A.N.; Présing, M.; Horváth, H.; Lamb, A.; Balzter, H.; et al. Validation of envisat MERIS algorithms for chlorophyll retrieval in a large, turbid and optically-complex shallow lake. Remote Sens. Environ. 2015, 157, 158-169. [CrossRef]

42. Wang, L.; Pu, H.; Sun, D.-W. Estimation of chlorophyll-a concentration of different seasons in outdoor ponds using hyperspectral imaging. Talanta 2016, 147, 422-429. [CrossRef] [PubMed]

43. Loisel, H.; Vantrepotte, V.; Ouillon, S.; Ngoc, D.D.; Herrmann, M.; Tran, V.; Mériaux, X.; Dessailly, D.; Jamet, C.; Duhaut, T.; et al. Assessment and analysis of the chlorophyll-a concentration variability over the vietnamese coastal waters from the MERIS ocean color sensor (2002-2012). Remote Sens. Environ. 2017, 190, 217-232. [CrossRef]

44. Le, C.; Hu, C.; Cannizzaro, J.; English, D.; Muller-Karger, F.; Lee, Z. Evaluation of chlorophyll-a remote sensing algorithms for an optically complex estuary. Remote Sens. Environ. 2013, 129, 75-89. [CrossRef]

45. Gitelson, A.A.; Schalles, J.F.; Hladik, C.M. Remote chlorophyll-a retrieval in turbid, productive estuaries: Chesapeake bay case study. Remote Sens. Environ. 2007, 109, 464-472. [CrossRef]

46. Hu, C.; Chen, Z.; Clayton, T.D.; Swarzenski, P.; Brock, J.C.; Muller-Karger, F.E. Assessment of estuarine water-quality indicators using MODIS medium-resolution bands: Initial results from tampa bay, FL. Remote Sens. Environ. 2004, 93, 423-441. [CrossRef]

47. Chen, J.; Quan, W. An improved algorithm for retrieving chlorophyll-a from the yellow river estuary using MODIS imagery. Environ. Monit. Assess. 2012, 185, 2243-2255. [CrossRef] [PubMed]

48. Sun, D.; Hu, C.; Qiu, Z.; Cannizzaro, J.P.; Barnes, B.B. Influence of a red band-based water classification approach on chlorophyll algorithms for optically complex estuaries. Remote Sens. Environ. 2014, 155, $289-302$. [CrossRef]

49. Toming, K.; Kutser, T.; Laas, A.; Sepp, M.; Paavel, B.; Nõges, T. First experiences in mapping lake water quality parameters with Sentinel-2 msi imagery. Remote Sens. 2016, 8, 640. [CrossRef]

50. Oliveira, A.M.; Kjerfve, B. Regular article: Environmental responses of a tropical coastal lagoon system to hydrological variability: Mundaú-manguaba, brazil. Estuar. Coast. Shelf Sci. 1993, 37, 575-591. [CrossRef]

51. Mueller, J.; Davis, C.; Arnone, R.; Frouin, R.; Carder, K.; Lee, Z.P.; Steward, R.G.; Hooker, S.; Mobley, C.; McLean, S. Above-Water Radiance and Remote Sensing Reflectance Measurement and Analysis Protocols; Goddard Space Flight Space Center: Greenbelt, MD, USA, 2003; pp. 21-31.

52. Mobley, C.D. Estimation of the remote-sensing reflectance from above-surface measurements. Appl. Opt. 1999, 38, 7442-7455. [CrossRef] [PubMed] 
53. Rice, E.W.; Baird, R.B.; Eaton, A.D.; Clesceri, L.S. Standard Methods for the Examination of Water and Wastewater; American Public Health Association: Washington, DC, USA, 2005.

54. Lubac, B.; Loisel, H. Variability and classification of remote sensing reflectance spectra in the eastern english channel and southern north sea. Remote Sens. Environ. 2007, 110, 45-58. [CrossRef]

55. Martinez, J.-M.; Espinoza-Villar, R.; Armijos, E.; Silva Moreira, L. The optical properties of river and floodplain waters in the amazon river basin: Implications for satellite-based measurements of suspended particulate matter. J. Geophys. Res. Earth Surf. 2015, 120, 1274-1287. [CrossRef]

56. Matthews, M.W. A current review of empirical procedures of remote sensing in inland and near-coastal transitional waters. Int. J. Remote Sens. 2011, 32, 6855-6899. [CrossRef]

57. Gitelson, A. The peak near $700 \mathrm{~nm}$ on radiance spectra of algae and water-relationships of its magnitude and position with chlorophyll concentration. Int. J. Remote Sens. 1992, 13, 3367-3373. [CrossRef]

58. Stumpf, R.P.; Tyler, M.A. Satellite detection of bloom and pigment distributions in estuaries. Remote Sens. Environ. 1988, 24, 385-404. [CrossRef]

59. Ruddick, K.G.; De Cauwer, V.; Park, Y.-J.; Moore, G. Seaborne measurements of near infrared water-leaving reflectance: The similarity spectrum for turbid waters. Limnol. Oceanogr. 2006, 51, 1167-1179. [CrossRef]

60. Mélin, F.; Vantrepotte, V. How optically diverse is the coastal ocean? Remote Sens. Environ. 2015, 160, $235-251$. [CrossRef]

61. Silva, E.D.A.; Nogueira, E.M.S.; Dué, A.; Carnaúba, M.P.; Guedes, E.A.C. Microalgas perifiticas em caiçaras situadas nas lagoas: Mundaú e manguaba do sistema lagunar de maceió. In Congresso de Ecologia do Brasil; Sociedade de Ecologia do Brasil (SEB): Caxambu, Brazil, 2005. Available online: www.seb-ecologia.org.br/ viiceb/resumos/31a.pdf (accessed on 21 October 2016).

62. Mobley, C.D. Light and Water: Radiative Transfer in Natural Waters; Academic Press: Cambridge, MA, USA, 1994; p. 592.

63. Brezonik, P.L.; Olmanson, L.G.; Finlay, J.C.; Bauer, M.E. Factors affecting the measurement of cdom by remote sensing of optically complex inland waters. Remote Sens. Environ. 2015, 157, 199-215. [CrossRef]

64. Mishra, S.; Mishra, D.R.; Lee, Z.; Tucker, C.S. Quantifying cyanobacterial phycocyanin concentration in turbid productive waters: A quasi-analytical approach. Remote Sens. Environ. 2013, 133, 141-151. [CrossRef]

65. Lyu, H.; Wang, Q.; Wu, C.; Zhu, L.; Yin, B.; Li, Y.; Huang, J. Retrieval of phycocyanin concentration from remote-sensing reflectance using a semi-analytic model in eutrophic lakes. Ecol. Inform. 2013, 18, 178-187. [CrossRef]

66. Tao, B.; Mao, Z.; Pan, D.; Shen, Y.; Zhu, Q.; Chen, J. Influence of bio-optical parameter variability on the reflectance peak position in the red band of algal bloom waters. Ecol. Inform. 2013, 16, 17-24. [CrossRef]

67. Binding, C.E.; Bowers, D.G.; Mitchelson-Jacob, E.G. Estimating suspended sediment concentrations from ocean colour measurements in moderately turbid waters; the impact of variable particle scattering properties. Remote Sens. Environ. 2005, 94, 373-383. [CrossRef]

68. Augusto-Silva, P.B.; Ogashawara, I.; Barbosa, C.C.F.; De Carvalho, L.A.S.; Jorge, D.S.F.; Fornari, C.I.; Stech, J.L. Analysis of MERIS reflectance algorithms for estimating chlorophyll- $\alpha$ concentration in a brazilian reservoir. Remote Sens. 2014, 6, 11689-11707. [CrossRef]

(C) 2017 by the authors. Licensee MDPI, Basel, Switzerland. This article is an open access article distributed under the terms and conditions of the Creative Commons Attribution (CC BY) license (http://creativecommons.org/licenses/by/4.0/). 